\title{
Prioritisation of Sustainable Supply Chain Practices with Triple Bottom Line and Organisational Theories: Industry and Academic Perspectives
}

\begin{abstract}
The purpose of this study is to investigate the influence of sustainable supply chain management (SSCM) practices on triple bottom line (TBL) measures from the perspective of organisational theories. This study identified five SSCM practices using a comprehensive literature review and feedback from industry experts. These five practices were prioritised using a fuzzy analytical hierarchy process (FAHP). The results from FAHP analysis were further confirmed by conducting semi-structured interviews in five electronics parts/components manufacturing organisations. This study also prioritised theoretical drivers of SSCM adoption based on the consideration of three organisational theory perspectives - Institutional Theory; Resource-based View, and; Social Network Theory. The results indicate that the economic dimension was the most important measure for implementing SSCM while sustainable design was the most important SSCM practice for achieving the TBL. The study also found that Institutional Theory is the most important theoretical driver for implementing SSCM. The research findings provide insight for management to allocate necessary resources and to develop effective strategic directions for the implementation of SSCM practices.
\end{abstract}

Keywords: sustainable supply chain, triple bottom line, fuzzy AHP, organisational theories 


\section{Introduction}

Sustainable supply chain management (SSCM) practices have become an imperative for businesses across the world (Arampantzi and Minis 2017; Thamsatitdej et al. 2017) and research on their impact has become increasingly important. The emergence of the concept of the triple bottom line (TBL) of economic, environmental and social performance has enabled organisations to consider the impact of SSCM practices from a wider perspective (Hollos, Blome, and Foerstl 2012; Anvari and Turkay 2017). The TBL approach has been used as the primary approach for assessing various sustainable supply chain practices (Govindan, Khodaverdi, and Jafarian 2013) and for increasing competitive advantage through the creation of sustainable supply chains (Ansari and Kant 2017; Anvari and Turkay 2017; Markley and Davis 2007). However, while there is evidence that organisations are increasingly considering the wider perspectives of SSCM (e.g. (Geissdoerfer et al. 2017; Lopes de Sousa Jabbour et al. 2018), academic research is yet to investigate or understand if all three dimensions of the triple bottom line (economic, environmental, and social) are considered to be equally important. The need for the study is driven by the acceptance that sustainability initiatives can play a significant role in achieving competitive advantage (Govindan, Khodaverdi, and Jafarian 2013). However, assessing sustainability within the context of TBL is a challenging issue because it is difficult to attribute performance to particular SSCM practices. In addition, lack of a systematic and integrated performance measurement framework hinders effective deployment of SSCM practices (Kuik et al. 2017; Ahi and Searcy 2015). Hence, this study is based on three research questions: (a) What is the relative ranking and importance of the three TBL measures when organisations decide to implement SSCM strategy?; (b) What is the relative importance among SSCM practices to achieve the different dimensions of the triple bottom line?; and (c) How is the adoption of SSCM practices motivated by three commonly used organisational theories (Institutional Theory, Resource-Based View Theory, and Social Network Theory)? 
In order to answer these research questions, this study examines the perception of researchers and industry managers. An understanding of the prioritisation described in the research questions would enable organisations that intend to implement a SSCM strategy concentrate their efforts and resources on the SSCM practices and TBL performance outcomes that best fit with the organisation's strategic objectives.

The remainder of the paper is structured as follows. A literature review of the key themes that underpin the study is presented. This is followed by an overview of the research methodology, highlighting the approach used and methods adopted for data collection, analysis and reporting. Then, results of the research are presented and are followed by a structured discussion. Finally, the study's conclusions are presented, along with practical implications, study limitations and future research directions.

\section{Review of literature}

SSCM has been described as a holistic approach to integrate all three TBL dimensions (Arampantzi and Minis 2017; Beske and Seuring 2014) and a means for sustainable development of upstream and downstream supply chain activities. Many organisations are recognising the need for sustainable supply chain practices (Ansari and Kant 2017; Diabat, Kannan, and Mathiyazhagan 2014; Grosvold, Hoejmose, and Roehrich 2014), as a result of various influencing factors including increased awareness of customer requirement for products and services that do not damage the environment (Govindan, Jha, and Garg 2016) and the need to gain competitive advantage (Sen 2009; Markley and Davis 2007). Other influencing factors include increasing environmental legislation and regulation in many countries (Somsuk and Laosirihongthong 2017).

Supply chain performance measurement has been studied extensively and discussed from different perspectives in the extant literature (Shepherd and Günter 2011; Schaltegger and Burritt 2014). These studies illustrate various methods and approaches adopted in the deployment of 
performance measurement across various industries and organisations. Some researchers (Ageron, Gunasekaran, and Spalanzani 2012; Bhattacharya et al. 2014; Ganga and Carpinetti 2011; Lai and Wong 2012; Turrisi, Manfredi, and Cannella 2013) have argued the importance of cohesive performance measures and matrices for sustainable supply chain management. These performance measures have been identified and categorised into various metrics by some review articles (Hassini, Surti, and Searcy 2012; Taticchi et al. 2015; Rajeev et al. 2017).

Arising from the existence of various drivers for SSCM adoption, many organisations have started implementing SSCM practices (Beske and Seuring 2014). However, organisations need to take the TBL approach into consideration and this can be a challenge because of different organisational and environmental complexities. Many challenges faced by industry were identified in the 2016 United Nations Global Compact-Accenture Strategy CEO study (Accenture 2017). It is the largest CEO study to date with over 1,000 survey responses and more than 50 one-to-one interviews with CEOs of leading organisations (Accenture, 2017). Although, in the 2016 study, 97\% of CEOs believe sustainability is important to the future success of their business compared to $48 \%$ in 2013 , only $14 \%$ strongly agreed that they were making efforts to meet the challenges. This was because of barriers such as lack of investor interest, lack of knowledge, implementing across business functions, difficult operating environment, extending through the supply chain, no clear link to business value, competing priorities and lack of financial resources.

Within the context of TBL, many studies on SSCM have focussed on the economic dimension and less so on the social dimension (Rajeev et al. 2017). Studies examining SSCM measures can be generally split into the following performance categories: (i) financial and non-financial measures, (ii) lean and non-lean measures, (iii) strategic, tactical and operational level measures, (iv) cost, time, quality and waste (Nagalingam, Kuik, and Amer 2013) flexibility and innovativeness; (v) balanced scorecard-based; (vi) qualitative and quantitative (Tseng et al. 2016), (vii) systems and process based (Chan and Qi 2003) (viii) economical, environmental and ethical measures (Laosirihongthong, 
Adebanjo, and Tan 2013). Each category has been extensively used in performance measurement systems including TBL measurement systems across a range of industries and supply chains.

Although SSCM practices have been indicated as being important in various industries, research in SSCM, and particularly quantitative research, is still at a preliminary stage (Ansari and Kant 2017). While the TBL approach has been researched in the academic literature with respect to measuring sustainable supply chain performance, the focus has mainly been on individual TBL dimensions rather than all three TBL dimensions simultaneously (Carter and Rogers 2008; Winter and Knemeyer 2013; Touboulic and Walker 2015; Tseng et al. 2016).

\subsection{Sustainable supply chain management and performance}

The broad range of performance measures, measurement methods, approaches and systems mean that selection of any approach for performance measurement in SSCM is complex and requires careful analysis. Research shows that by 2011, up to 98 individual performance measures had been used to assess sustainability in supply chains, but no study has holistically addressed all three dimensions of TBL (Hassini, Surti, and Searcy 2012). More recent research identified the used of more than 2555 individual metrics in SSCM performance measurement (Ahi and Searcy 2015). The diversity of these performance measures is validated by a recent review of more than 50 journal papers on the evolution of SSCM during 2000 to 2015 (Rajeev et al. 2017). Although the number of metrics used by various researchers increased tremendously over these years, most of these studies focused on a small number of core themes (Ahi and Searcy 2015; Rajeev et al. 2017). Similarly, having reviewed 384 articles from 2000 to 2013 on SSCM, Taticchi et al. (2015) stated that most of the existing research has not considered a holistic TBL approach for SSCM performance measurement.

\subsection{Industry measures for sustainable performance}

Laosirihongthong et al, (2013) examined the impact of green supply chain management (GSCM) 
practices on environmental, economic and intangible performance while Schaltegger and Burritt (2014) discussed the challenges in assessing sustainability in a supply chain's performance measurement and management. However, studies by Pagell and Shevchenko (2014) and Rajeev et al. (2017) have concurred with earlier articles (e.g. Taticchi et al., 2015) that the majority of ongoing research on SSCM ignore a holistic view of the TBL.

Hassini, Surti, and Searcy (2012) argued that external and internal pressures such as market forces, policy and regulations, developments in science and technology, product development requirements with environmental credentials, process capability expectations on greening existing processes, environmental friendly sourcing requirements, sustainable requirements on transport and logistics, marketing for creating value propositions with innovative credentials, emerging social issues and others may compel organisations to adopt sustainable operations. Due to this diversity of requirements, there are many performance measures/ matrices and methods in use in SSCM deployment. In order to propose guidelines for selection of appropriate measures, this study categorised these key measures by using the Supply Chain Operations Reference (SCOR) model. The SCOR model was established by the Supply-Chain Council in 1996 and been regularly updated to adapt to changes in supply chain business practices by APICS after the 2014 merger of APICA and the Supply-Chain Council (APICS 2017). Version 12 of the SCOR model provides a unique framework to support supply chain activities and to measure six primary management processes - Plan, Source, Make, Deliver, Return and Enable (APICS 2017). Although, SCOR and Global Supply Chain Forum (GSCF) models are the two most widely accepted and applied frameworks by industry (Murphy and Knemeyer 2018), SCOR was adopted for this study because it is more prominently used in industry (Taticchi et al. 2015). In addition, the focus of SCOR makes it an appropriate framework to achieve cross-functional business process evaluation and integration, while the GSCF framework is more appropriate for achieving external supply chain (SC) integration. 
APICS Operations Management Body of Knowledge Framework (APICS 2011) stated that 'sustainable supply chains seek clean methods of production, minimization of the environmental footprint of products and services, and combining environmentally friendly decisions with effective supply chain practices'. This study adopted the definition of SSCM by Ahi and Searcy (2013), and argues that the performance of SSCM primarily depends on the three pillars of TBL. Then, by applying SCOR processes to each of these pillars, the study proposes five second level factors - Sustainable design, Sustainable procurement, Sustainable Manufacturing, Sustainable distribution and Reverse logistics - for the hierarchy of decision making as shown in Figure 1.

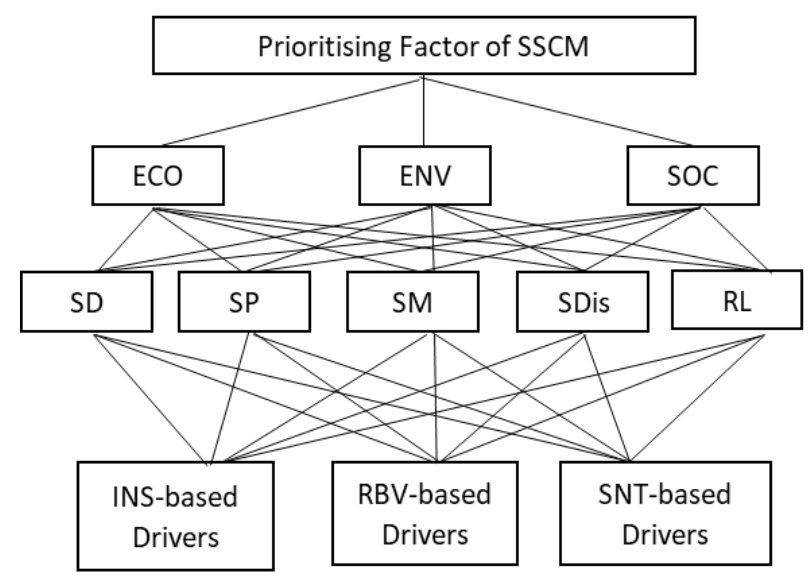

\begin{tabular}{|l|l|}
\hline Dimension Criteria & Codes \\
\hline Performance: The Triple Bottom Line & \\
Economic Dimension & ECO \\
Environment Dimension & ENV \\
Social Dimension & SOC \\
\hline Sustainable supply Chain Practice & \\
Sustainable Design & SD \\
Sustainable Procurement & SP \\
Sustainable Manufacturing & SM \\
Sustainable Distribution & SDis \\
Reverse Logistics & RL \\
\hline Organisational theory-based Drivers & \\
Institutional Theory-based Drivers & INS-D \\
Resource Based View-based Drivers & RBV-D \\
Social Network Theory-based Drivers & SNT-D \\
& \\
\hline
\end{tabular}

Figure 1. A hierarchical structure of SSCM practices, TBL measures and organisational theory-based drivers

Sustainable design is important in enhancing sustainable supply chain from upstream to downstream activities (Thamsatitdej et al. 2017) and relates to the "Plan" management process of SCOR. Sustainable design also helps achieve product sustainability, which is the ability to produce and distribute without exhausting non-renewable resources. Sustainable design also minimises impact on 
the environment (APICS 2011) by incorporating reduced material usage, recyclability, disassembly and others in the product design stage (Badurdeen et al. 2009; Salari and Bhuiyan 2016). Rajeev et al. (2017) suggested that focus on sustainable design practices can significantly enhance the other second level factors of SSCM.

The adoption of sustainable procurement is critical for successful implementation of SSCM (Prasad et al. 2018), and is relevant to most organisations in the supply chain (García-Villarreal, Bhamra, and Schoenheit 2019). Since procurement is a major and significant part of many organisations, sustainable procurement should be considered as key aspect of SSCM. Sustainable procurement is closely linked with sustainable design and is facilitated through the concept of green materials (Thamsatitdej et al. 2017). Sustainable procurement mainly focuses on the selection of suppliers with sustainable practices using supplier evaluation techniques (Govindan, Khodaverdi, and Jafarian 2013), and partnerships (Ageron, Gunasekaran, and Spalanzani 2012).

Sustainable manufacturing is the foundation for sustainability as it provides increased collaboration between product design/development and product recovery (Govindan, Jha, and Garg 2016; Badurdeen et al. 2009). In today's competitive environment, manufacturers need to adopt sustainable manufacturing activities (Nagalingam, Kuik, and Amer 2013) through greater utilisation of products with many recoverable components in order to reduce landfill (Kuik et al. 2017). Sustainable manufacturing aligns with the "Make" management process of SCOR.

Sustainable distribution is that suppliers need to deliver components and raw materials to manufacturers where these deliveries (deliver process of SCOR) need to incorporate attributes of sustainability. Sustainable distribution can also be achieved by having shorter and slimmer supply chains (Schaltegger and Burritt 2014).

Product return management in a supply chain (Turrisi, Manfredi, and Cannella 2013), is one of the key SCOR processes and is vital to improve the sustainability of the supply chain (Nagalingam, Kuik, and Amer 2013). When products are not biodegradable, a sustainable reverse logistics system is 
needed to achieve SSCM (Schaltegger and Burritt 2014). Hence, the 'Return' process of SCOR is mapped with reverse logistics in this study.

\subsection{Organisational theories and adoption of SSCM strategy}

It is clear from the literature review that although, traditional measurement dimensions of the TBL are widely used and developed in business performance, significant shortcomings exist in using integrated measures of TBL as it is less prevalent and much more difficult to implement. Organisation theories help to understand the motivation for SSCM adoption and therefore can affect the relationships between supply chain practices and integrated measures of TBL. In order to investigate the relationships between organisational theories and SSCM adoption, this study examined three prominent academic theories that drive SSCM adoption. Hence, in this study, 'organisational theories' is used as a collective term for the three specific theories that are studied.

Many relevant theories for SSCM adoption have been reviewed by researchers (Tachizawa and Wong 2014; Touboulic and Walker 2015). True theories for SSCM neither exist nor are used in practice (Reefke and Sundaram 2017). Hence, this study builds on the insights from three dominant theories namely, institutional theory, resource-based view theory and social network theory. Linking of appropriate theories to an empirical study can provide additional insights in the extant literature, as a single theory may not be able to explain SSCM fully. Touboulic and Walker (2015), in their review article, found that Resource based view (RBV), Stakeholder theory and Institutional theory are predominantly used by researchers. They also found that although, SSCM signifies an evolution of business practise from SCM, SSCM is not fully explored with other theoretical views such as social network theory or social exchange theory (Touboulic and Walker 2015) yet.

Institutional theory is employed to explain the effect of external pressures on accepting new organisational behaviors and analysing the legitimacy of organisational practices. With institutional theory, there are three forms of isomorphic drivers namely, coercive, mimetic and normative 
(DiMaggio and Powell 1983; Glover et al. 2014). Coercive pressures emanate from powerful stakeholders (Glover et al. 2014) and includes government laws and regulations. Mimetic pressure relates to an organisation's choice to imitate their competitors (DiMaggio and Powell 1983) in adopting SSCM practices and activities (Shibin et al. 2017). Normative drivers which make organisations comply with social obligations (Glover et al. 2014), can arise from trade/ professional associations (DiMaggio and Powell 1983) and similar group of firms (Shibin et al. 2017).

In contrast, resource based view (RVB) suggests that competitive advantage can be sustained by harnessing resources that are rare, valuable and difficult to imitate (Barney 1991). RBV evolved 20 years later into resource-based theory (RBT), with the argument that the RBV had reached a level of sophistication and more resembled a theory than a view (Barney et al, 2011). Therefore, researchers started using the term 'RBT' instead of RBV. However, many researchers still use RBV instead of RBT. RBV in SSCM suggests organisations gain competitive advantage by utilising unique competencies in ensuring sustainability (Touboulic and Walker 2015).

Although, institutional theory allows researchers to explore the role of regulatory and social pressures in sustainability actions (Glover et al. 2014), social network theory provides a framework to view the performance of a supply chain member in relation to the structure of the extended supply network the member is associated with (Tachizawa and Wong 2014). Social network theory values social relationships between organisations and individuals as key factors for organisational performance. Supply chains are complex and characterised by interconnected networks, relationships and activities. Hence, social network theory should be included with other management theories in assessing and explaining the inter-organisational processes of a supply chain (Gold, Seuring, and Beske 2010).

\section{Research methodology}

This research adopted a mixed method research methodology. First, experiences and perceptions of 
experts in implementing SSCM were determined. Data was collected from twenty experts consisting of ten practitioners (operational level) from electronics parts/components manufacturing companies based in Thailand and ten academics/researchers with experience of SSCM research. They were asked to determine the relative weight of importance among TBL dimensions, SSCM practices, and organisational drivers by using Fuzzy Analytical Hierarchy Process (FAHP). Thereafter, semistructured interviews were conducted with five industry experts (top management level) to further clarify the degree of importance identified in the FAHP analysis.

\subsection{AHP/FAHP analysis}

Conventional AHP was conceived by Dr Thomas Saaty in early 80's (Saaty 1994) and has been widely used to solve multi-criterion decision-making problems in SSCM (Ansari and Kant 2017; Taticchi et al. 2015). However, the comparison scales of AHP cannot handle uncertainty and fuzziness associated with individual measures. In contrast, the fuzzy set theory helps to conceptualise fuzziness in human reasoning and to reach deterministic decision outputs when existing assessment techniques are imprecise, complex, incomplete, unreliable or not holistic (Govindan, Khodaverdi, and Jafarian 2013). FAHP, therefore, provides a suitable approach to address the research question on prioritisation of SSCM practice in achieving TBL measurement. FAHP combines the best of fuzzy set theory and AHP to handle fuzziness of key inputs into a multi-criteria decision-making process (Chang 1996). Hence, linguistic scales of the fuzzy set theory were used in the pair-wise comparison of each criterion to overcome uncertainty conditions of decision criteria (Chang 1996; Tseng et al. 2016; Somsuk and Laosirihongthong 2017). Linguistic scales and triangular fuzzy scales adopted in this research are shown in Table 1. 
Table 1. Fuzzy linguistic scales for comparison

\begin{tabular}{ll}
\hline Linguistic scale & Triangular fuzzy scale \\
\hline Equally preferred & $(1,1,3)$ \\
Equally to moderately preferred & $(1,3,5)$ \\
Moderately preferred & $(3,5,7)$ \\
Very strongly preferred & $(5,7,9)$ \\
Extremely preferred & $(7,9,9)$ \\
& \\
\hline
\end{tabular}

A three-layered hierarchical structure was constructed to evaluate experts' ranking of SSCM practices, based on various conflicting criteria associated with three major categories of performance measures; and to reveal which organisational theory explains the rationale for adoption of each SSCM practice. Similar to (Reefke and Sundaram 2017), this study integrated the insights from literature with the practical inputs from industry practitioners and organisational theories. Figure 1 shows the hierarchy for the prioritisation. The first level of the hierarchy structure is the TBL dimension while the second level of the structure consists of five major categories of SSCM practices based on SCOR. At the third level, rationale for SSCM adoption are grouped into three organisational theories that were associated to this research since theoretical lenses provide validity and help form empirical reality (Touboulic and Walker 2015). These three theories were explained to the senior managers who took part in the FAHP ranking.

To evaluate academic and industry perspectives about TBL, twenty experts with ten from each group were asked to determine the relative weights among criteria shown in the AHP structure. The first group were ten professional/industry experts in Thailand while the second group were academics/researchers. The main criteria for the selection of industry experts were (i) working in electronic parts/components manufacturing industry over 10 or more years, (ii) at middle-to-top management level, and (iii) the company considers sustainability as a top priority in their manufacturing strategy and have ISO 14001 certification. For the experts from academia, all were 
selected based on the main criteria of (i) at least 10 years of research experience, (ii) actively engaged in research on the topic of SSCM, and (iii) published on the topic during the past 5 years $(2014-2018)$ with at least 10 articles published in reputable international/national journals.

In the first level of analysis, the relative importance of each TBL dimension with respect to the goal was obtained. In the second level, the relative importance of the five SSCM practices with respect to immediate higher-level criteria (TBL dimension) was obtained. Finally, how the three selected organisational theories motivate organisations to implement SSCM practices were evaluated. The final weights of each sub-criterion with respect to the higher level were obtained through the synthesis of normalised priority weights.

\subsection{Semi-structured interviews}

The second stage of data collection was completed using semi-structured interviews of key stakeholders in electronics parts/components manufacturing companies. A total of five semi-structured interviews were conducted with senior executives in five organisations. The interview questions were designed to complement and explain the findings from the first stage. There was a particular focus on the importance of drivers for SSCM adoption and clarification on why some dimensions of SSCM were considered to be more important than others. Table 2 shows the details of the interviewees.

Table 2. Profile of interviewees

\begin{tabular}{|c|l|l|l|l|}
\hline Company & \multicolumn{1}{|c|}{ Interviewee } & Experience & \multicolumn{1}{c|}{ Key product } & \multicolumn{1}{c|}{ Company details } \\
\hline W & $\begin{array}{l}\text { VP, Global Supply } \\
\text { Chains }\end{array}$ & $>20$ years & Digital Storage & $\begin{array}{l}\text { Multinational with }>20,000 \\
\text { Thai employees }\end{array}$ \\
\hline N & $\begin{array}{l}\text { Director, } \\
\text { Manufacturing Div. }\end{array}$ & $>20$ years & Digital Storage & $\begin{array}{l}\text { Multinational with more than } \\
50 \% \text { global market share }\end{array}$ \\
\hline E & $\begin{array}{l}\text { Director, Supply } \\
\text { Chain }\end{array}$ & $>15$ years & $\begin{array}{l}\text { Home } \\
\text { Appliances }\end{array}$ & $\begin{array}{l}\text { Multinational with }>50,000 \\
\text { employees }\end{array}$ \\
\hline D & VP, Manufacturing & $>25$ years & $\begin{array}{l}\text { Elec. } \\
\text { components }\end{array}$ & $\begin{array}{l}\text { Multinational with sales to } \\
\text { major OEMs }\end{array}$ \\
\hline T & $\begin{array}{l}\text { Director, Global } \\
\text { supply Chain }\end{array}$ & $>25$ years & $\begin{array}{l}\text { Elec. } \\
\text { components }\end{array}$ & $\begin{array}{l}\text { Multinational in top 3 in their } \\
\text { category }\end{array}$ \\
\hline
\end{tabular}




\section{Results}

The results from the first stage (FAHP analysis based on inputs from twenty experts in the electronic parts/components manufacturing companies and academic researchers) indicate that among the three dimensions of TBL, the economic dimension is the most important aspect for prioritisation of SSCM practices (see Figure 2). Among SSCM activities, sustainable design was identified as the most important activity for SSCM across all three dimensions (see Figure 3A-3C). Furthermore, the primary theoretical driver for SSCM adoption for industry practitioners was institutional theory, which implies external drivers such governmental policies, laws and regulations (see Table 3). To gain better understanding of experts' opinion, in terms of relative importance of each SSCM practice on TBL measures and overall impact, the results are separated into three parts: TBL dimensions; SSCM practices; and SSCM adoption through organisational theories.

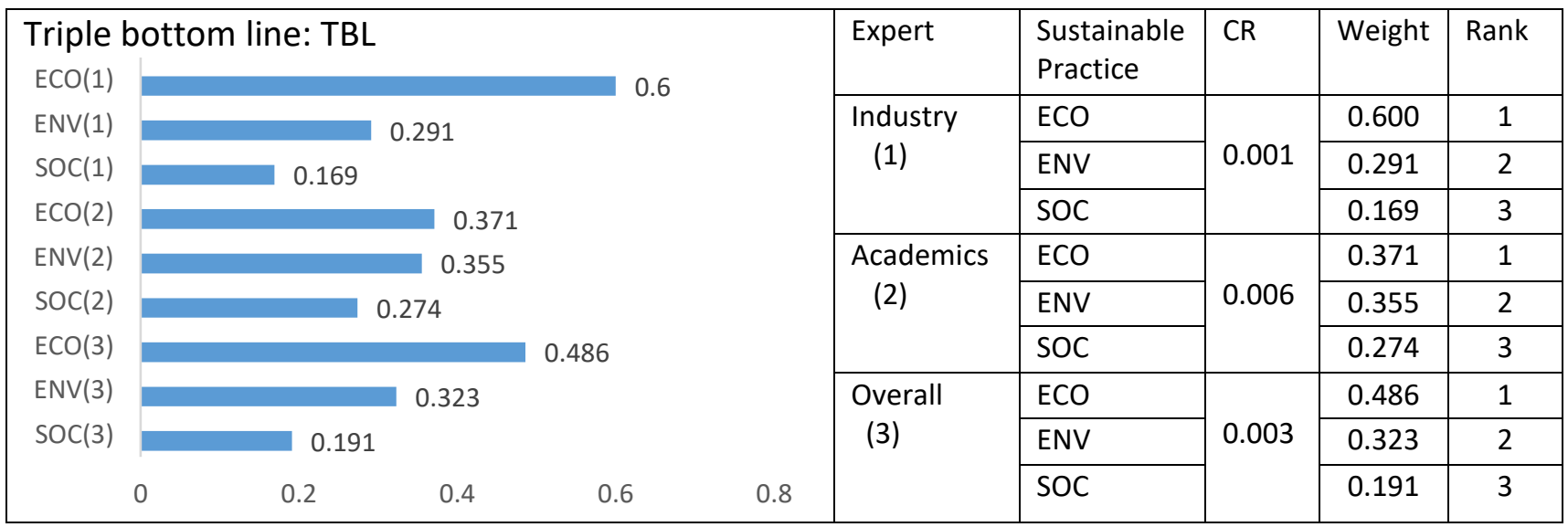

Figure 2. Prioritisation of TBL measures on SSCM practice, from the perspective of industry experts and academic researchers

\begin{tabular}{|c|c|c|c|c|c|}
\hline 1. Economic dimension & Experts & $\begin{array}{l}\text { Sustainable } \\
\text { Practice }\end{array}$ & CR & Weight & Rank \\
\hline & \multirow{5}{*}{$\begin{array}{l}\text { Industry } \\
\text { (1) }\end{array}$} & SD1 & \multirow{5}{*}{0.074} & 0.343 & 1 \\
\hline & & SP1 & & 0.105 & 5 \\
\hline & & SM1 & & 0.198 & 2 \\
\hline & & SDis1 & & 0.178 & 3 \\
\hline & & RL1 & & 0.176 & 4 \\
\hline
\end{tabular}




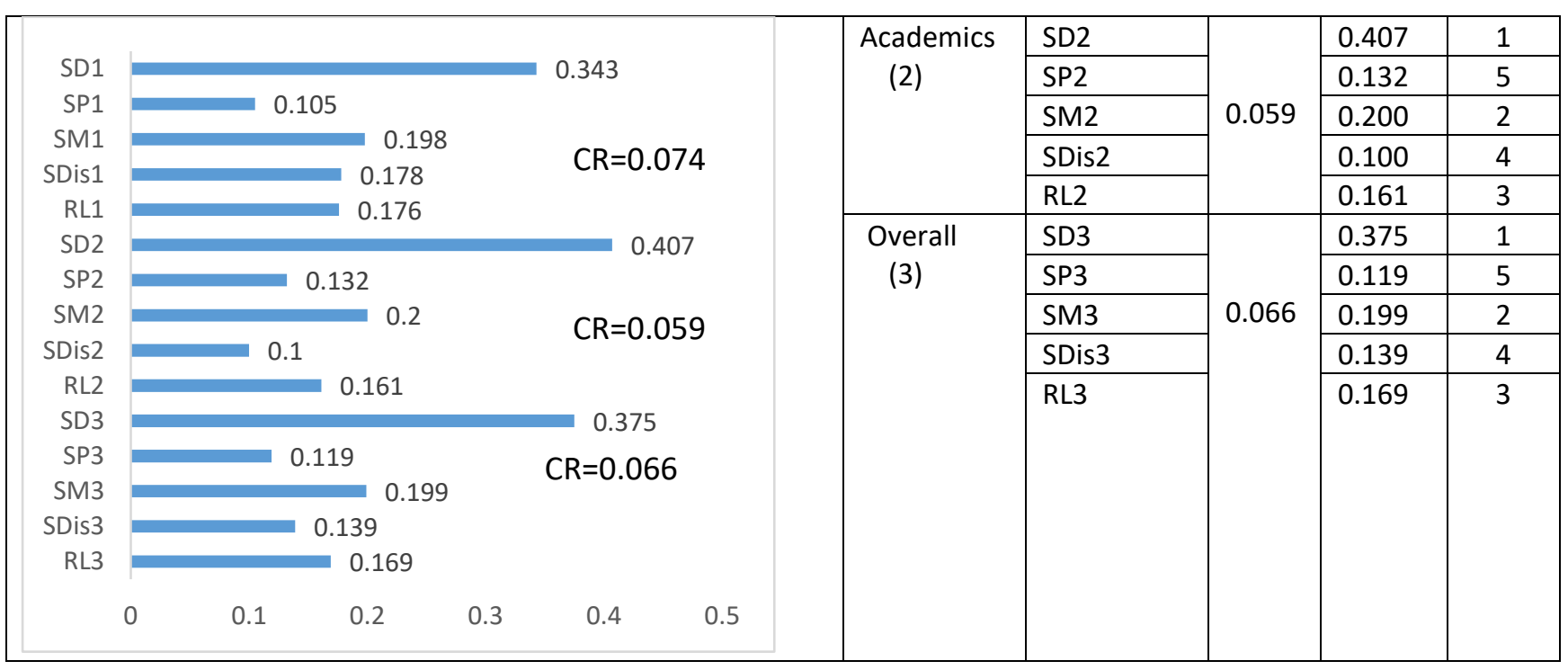

Figure 3A. Prioritisation of sustainable practice - Economic dimension perspective 


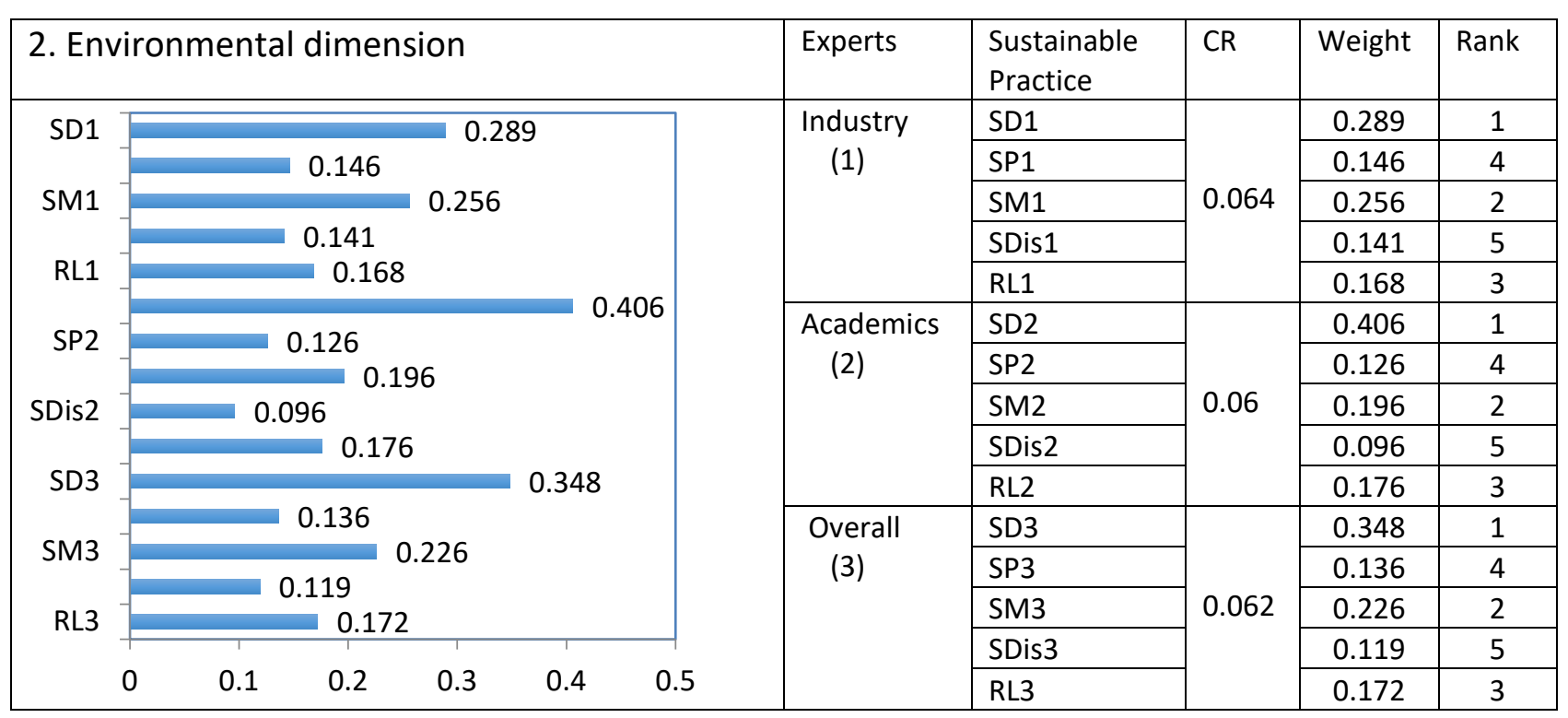

Figure 3B. Prioritisation of sustainable practice - Environmental dimension perspective

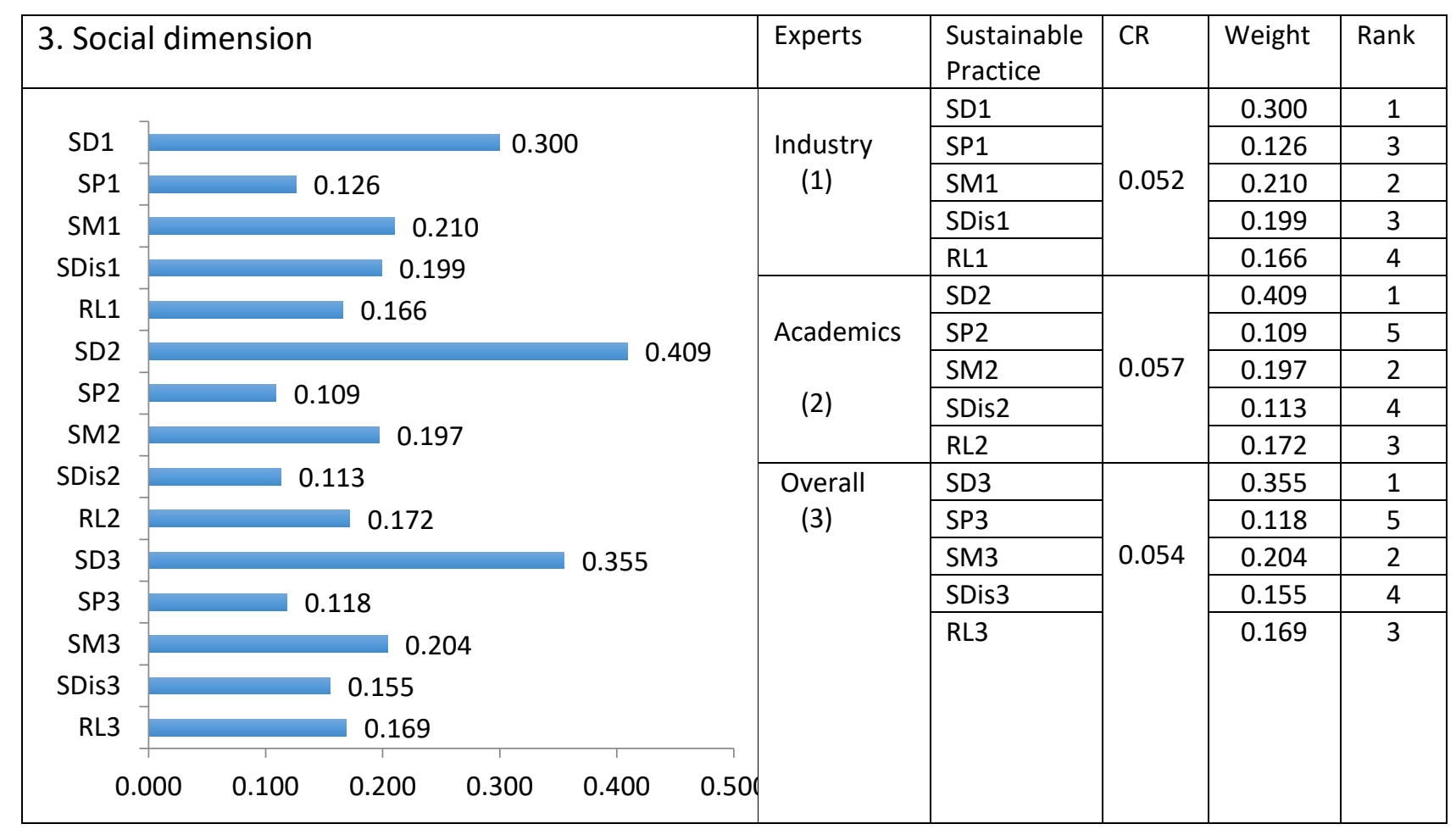

Figure 3C. Prioritisation of sustainable practice - Social dimension perspective

Figures 3 (A-C) Prioritisation of SSCM practice in each TBL measure 


\section{1 Prioritisation of TBL in achieving SSCM implementation}

It can be noticed from Figure 2 that there was a consensus from both groups of experts that the economic dimension was the most important dimension $(0.486)$ followed by the environment $(0.323)$ and the social (0.191) dimensions respectively. However, when considering the differences between the emphasis placed on the three dimensions between the academic experts and the industry experts, there is an interesting observation. The findings indicated that industry experts overwhelmingly believed that the economic dimension (0.600) is more important than the combined dimensions of environment (0.291) and social (0.169). In contrast, the academic experts indicated a more balanced emphasis across the three dimensions with the economic dimensions weighted at $(0.371)$ while the environment and social dimensions were weighted at 0.355 and 0.274 respectively.

\subsection{Prioritisation of SSCM practice in achieving each TBL measure}

The data was also analysed by investigating the impact of the sustainable practices on each dimension of the TBL. This information is shown in Figure 3. With respect to the economic dimension, the combined results of academic and industry experts indicated that sustainable design (0.375) is the most important practice, followed by sustainable manufacturing (0.199), reverse logistics (0.169), sustainable distribution (0.139) and sustainable purchasing (0.119). When contrasting the responses between the academic and industry experts, the singular difference in ranking was that industry experts considered sustainable distribution $(0.178)$ to be slightly more important than reverse logistics $(0.176)$ while academic experts considered reverse logistics $(0.161)$ to be more important than sustainable distribution (0.100).

When considering the environment dimension, the combined results of academic and industry experts indicated that sustainable design (0.348) was the most important practice and followed by sustainable manufacturing (0.226) and reverse logistics $(0.172)$. The lowest ranked practices were sustainable purchasing (0.136) and sustainable distribution (0.119). Therefore, in comparison to the 
economic dimension, the three most important practices are the same. Furthermore, within the context of the environment dimension, there was no difference in ranking between academic and industry experts.

Finally, when considering the social dimension, the combined result of academic and industry experts indicated that sustainable design (0.355) was the most important practice and followed by sustainable manufacturing (0.204) and reverse logistics (0.169). The lowest ranked practices were sustainable distribution (0.155) and sustainable purchasing (0.118). Therefore, the ranking for the social dimension is similar to the ranking for the economic dimension. Within the context of the social dimension, when contrasting the responses between the academic and industry experts, the singular difference in ranking was that industry experts considered sustainable distribution (0.199) to be more important than reverse logistics $(0.166)$ while academic experts considered reverse logistics $(0.172)$ to be more important than sustainable distribution (0.113).

\subsection{Prioritisation of organisational theory-based drivers that influences the adoption of each SSCM practice.}

The data on theory-based drivers that influence the adoption of the different SSCM practices is presented in Table 3 and indicate that for the adoption of sustainable design, institutional theory (0.45), followed by RBV (0.315) and lastly, SNT (0.235) are important. The ranking is identical for the adoption of sustainable manufacturing with institutional theory having a weighting of 0.514 , followed by RBV (0.316) and SNT (0.171). However, for sustainable purchasing, while institutional theory (0.46) was ranked highest, SNT (0.341) was second and followed by RBV (0.199). The rankings for sustainable distribution were identical to sustainable purchasing with institutional theory $(0.413)$ ranked highest, followed by SNT (0.326) and then RBV (0.262). 
Table 3. Global weights and rankings of SSCM practices from organisational theory-based driver perspectives.

\begin{tabular}{|c|c|c|c|c|c|c|c|}
\hline \multirow[t]{2}{*}{ SSCM Practices } & \multirow{2}{*}{$\begin{array}{l}\text { Organisational } \\
\text { Theory-based } \\
\text { Drivers }\end{array}$} & \multicolumn{2}{|c|}{ Industry Expert } & \multicolumn{2}{|c|}{$\begin{array}{l}\text { Academic } \\
\text { Expert }\end{array}$} & \multicolumn{2}{|c|}{ Overall } \\
\hline & & Weight & Rank & Weight & Rank & Weight & Rank \\
\hline \multirow[t]{3}{*}{ Sustainable design } & INS-D & 0.492 & 1 & 0.408 & 1 & 0.45 & 1 \\
\hline & RBV-D & 0.325 & 2 & 0.305 & 2 & 0.315 & 2 \\
\hline & SNT-D & 0.183 & 3 & 0.287 & 3 & 0.235 & 3 \\
\hline \multirow[t]{3}{*}{ Sustainable purchasing } & INS-D & 0.433 & 1 & 0.487 & 1 & 0.46 & 1 \\
\hline & RBV-D & 0.259 & 3 & 0.139 & 3 & 0.199 & 3 \\
\hline & SNT-D & 0.308 & 2 & 0.374 & 2 & 0.341 & 2 \\
\hline \multirow[t]{3}{*}{ Sustainable manufacturing } & INS-D & 0.533 & 1 & 0.495 & 1 & 0.514 & 1 \\
\hline & RBV-D & 0.367 & 2 & 0.264 & 2 & 0.316 & 2 \\
\hline & SNT-D & 0.1 & 3 & 0.241 & 3 & 0.171 & 3 \\
\hline \multirow[t]{3}{*}{ Sustainable distribution } & INS-D & 0.469 & 1 & 0.357 & 2 & 0.413 & 1 \\
\hline & RBV-D & 0.279 & 2 & 0.244 & 3 & 0.262 & 3 \\
\hline & SNT-D & 0.252 & 3 & 0.399 & 1 & 0.326 & 2 \\
\hline \multirow[t]{3}{*}{ Reverse logistics } & INS-D & 0.361 & 1 & 0.323 & 3 & 0.342 & 2 \\
\hline & RBV-D & 0.345 & 2 & 0.345 & 1 & 0.345 & 1 \\
\hline & SNT-D & 0.294 & 3 & 0.332 & 2 & 0.313 & 3 \\
\hline
\end{tabular}

The final category of reverse logistics was the only category for which institutional theory was not ranked as the most influential driver. Rather, RBV (0.345) was ranked highest and followed by institutional theory (0.342) and last was SNT (0.313).

\subsection{Interview findings}

To further investigate the key reasons for adoption of different practices, semi-structured interviews were conducted in five major electronics parts/components manufacturing companies in Thailand. Key findings from the interviews are presented as follows.

External stakeholders (government, end customers) are considered influential in environmental sustainability of SSCM (Meixell and Luoma 2015). The interviewees were asked which external 
influences (government, customers, suppliers, competitors) where the most influential in driving adoption of sustainable practices. Companies T, D and W were clear that government regulations in their export countries were the most important factor. The interviewee from company W said,

"WEEE, which stands for Waste from Electrical and Electronic Equipment, is considered as an order qualifier for our industry to export products to EU markets. This regulation mandates the treatment, recovery and recycling of electric and electronic equipment (90\% ends up in landfills)".

On the other hand, pressure from customers was the most influential factor for the adoption of sustainable practices by companies $\mathrm{E}$ and $\mathrm{N}$. However, it was also clear from company $\mathrm{N}$ that the regulations in export countries (WEEE and RoHS) were important aspects of the customers' overall requirements. The interviewee from company $\mathrm{N}$ said,

“To be qualified as an approved supplier/vendor, we were asked by customer to design and implement management systems that comply with ISO 14001 Standard”.

To further investigate the influence of government and regulations, the interviewees were asked which approaches by government were more influential in encouraging adoption of sustainable practices. Specifically, they were asked if incentive policies or punitive policies were more likely to drive adoption of sustainable practices. The results indicate that there was unanimity among the respondents that incentive factors were more influential. For example, company D said,

"To move forward to SSCM strategy, our company has been initially supported by the Ministry of Industry including financial incentives, environmental seminars, and tax incentives (i.e. exemption in VAT for environmentally friendly materials). Our Tier 1 suppliers are also encouraged to apply environmental management systems - ISO 14000 for ensuring compliance and proper waste management systems. All of them received partial financial support by Department of Industrial Promotion to employ professional consultants". 


\subsubsection{The importance of sustainable practices}

The findings from the FAHP analyses indicated clearly that sustainable design was seen the most important sustainable practice and in order to investigate why it was so highly ranked, the interviewees were asked why it was considered to be more important than other sustainable practices. The key indication from the five companies is that sustainable design has very significant impacts on the environment by enabling products and processes to be sustainable even before the start of production. For example, company $\mathrm{E}$ and company $\mathrm{T}$ respectively said,

"Our company has been working closely with the Sustainability Research Centre in the university to develop measurement systems for the life cycle (LC) of products. We will use this information as a design input of our products in order to sustain users (people) and society. As the result, implementing sustainability concept will be more efficient along the supply chain".

and

"By putting the concept of sustainability in design process, waste and environmental impact could be reduced and prevented before the production process starts".

The respondents were also asked why sustainable purchasing was seen as less important than other practices. The indication from the respondents is that their local suppliers either do not understand the importance of sustainable practices or do not have the resources/policies to drive their adoption. Company E said,

"Unfortunately, in the reality, most of our suppliers do not understand why sustainability is important. It could be explained that most of them are small-to-medium size company where low-cost-production has been considered as a top priority. Therefore, sustainable purchasing will not be important, at this stage". 
In addition, company $\mathrm{N}$ and $\mathrm{T}$ indicated that they were sometimes powerless in their ability to choose suppliers and that their customers played a key role in their choices. Specifically, company $\mathrm{N}$ said,

“Most of local suppliers have been recommend by our key customers. We can’t do much with them in implementing the concept of SSCM".

However, it is also clear that there are increasing efforts by all five companies to encourage their suppliers to be more sustainable in their operations. Company $\mathrm{N}$ said,

"To be eligible for being our long-term partner, all key suppliers have to comply with our standards/requirements." while company D said, "We are now working with key suppliers (6-10 companies) to help them cut their location-based energy use. We also share best practices on energy saving and 3Rs - Reduce/Reused/Recycle”.

The respondents were then asked about the relatively low ranking of sustainable distribution. The key message from the companies was that while they keep an eye on sustainable distribution, it was not a core priority and that their core priority were their competencies in manufacturing. Company W said,

"We are a manufacturing-based company while distribution is focusing on dispatching activity only. However, what we always do, especially for transportation, is outsourcing to 3PL. And, of course, sustainability measure is one of the selection criteria".

This view was similar to company E which said,

"These activities have been considered as a support function while design and manufacturing are the main focus. Hence, when we aim to achieve the sustainable measures (RoHS or WEEE) required by the key customers, distribution activities are important but do not have priority". 
The importance of sustainable manufacturing as a core priority and competence of the companies was further stressed by the interviewees. Company $\mathrm{T}$ said,

"Manufacturing is normally a key and important activity that creates the environmental impacts. In our company, we believe that if the concept of sustainability is implemented from material sourcing to delivering finished products to customer, all types of waste will be reduced significantly".

Company $\mathrm{N}$ went further and clarified the importance of waste reduction by identifying the financial benefits that have accrued from adopting sustainable manufacturing practices, by stating as follows:

"I could give you examples of how sustainable manufacturing pays. After designing and implementing number of practices in our manufacturing process, energy efficiency improvements have saved us almost THB 20 million (USD 667,000) per year”.

\section{Discussion}

The findings from the study have provided valuable new insights into the understanding of perceptions of relative importance of the elements of the TBL. Previous studies (Rajeev et al. 2017; Meixell and Luoma 2015; Beske and Seuring 2014; Govindan, Khodaverdi, and Jafarian 2013; Winter and Knemeyer 2013; Carter and Rogers 2008) have noted the importance of the TBL within the context of SSCM, and recent studies (Seuring, Brix-Asala, and Khalid 2019; Bai and Sarkis 2018) have emphasised the need to manage and consider trade-offs among TBL measures. This is because there is no clear understanding regarding how the elements of the TBL are regarded relative to each other. This study has also investigated differences in perception between industry practitioners and academic experts. The findings are discussed as follows. 


\subsection{Relative importance of triple bottom line $(T B L)$}

The study indicated that the economic dimension was regarded as the most important, followed by the environment dimension while the social dimension was ranked third. This finding clearly indicates that while the environmental and social benefits of adopting SSCM practices are within the conscious thinking of organisations, adoption of such practices need to make economic sense. The high importance given to this dimension by the industry experts leads the researchers to suggest that even if adoption of certain SSCM practices have high environmental and social benefits, if the adoption of such benefits have low or negative economic consequences, organisations may be reticent to adopt them. This may explain why previous studies have been inconclusive about the successes that organisations have had with respect to SSCM practices. While some studies (Rajeev et al. 2017; Beske and Seuring 2014; Bai and Sarkis 2018; Hong, Zhang, and Ding 2017; Carter and Rogers 2008) have found such adoption to be beneficial, others (Wang and Sarkis 2013; Geng, Mansouri, and Aktas 2017) have found adoption of SSCM practices to be detrimental to the economic performance, in particular at early stages of the adoption. For emerging economies, although SSCM practices lead to environmental performance, they may not result in improved cost performance (Esfahbodi, Zhang, and Watson 2016).

The study showed that there was unanimity in the rankings between the academic experts and the industry experts, but it was important to note that the industry experts rated the importance of the economic dimension much higher than the academic experts. The fact that they rated it as more important than the combined effect importance of the environment and social dimensions has two important implications. First, it provides strong evidence to support the conclusion that the environment and social benefits/attributes of SSCM practices are unlikely to overcome economic considerations. Second, it suggests that the academic community may not be fully appreciative of the level of importance that industry ascribes to the economic implications of actions that they take. 
Therefore, while researchers take a more balanced view of the TBL (Bai and Sarkis 2018; Hong, Zhang, and Ding 2017; Somsuk and Laosirihongthong 2017; Beske and Seuring 2014) and tout the importance of environmental and social impacts(Markley and Davis 2007), for industry managers, economic impacts trump all other considerations.

Apart from the economic dimension, the environment dimension was strongly influenced by sustainable design and sustainable manufacturing. When combined with the findings from the interviews, the indication from this study is that there is a strong linkage between the perceived core competencies of an organisation and how its focus on the core competencies motivates which sustainable practices it adopts. Therefore, while it is generally agreed that sustainable purchasing and sustainable distribution (Prasad et al. 2018; García-Villarreal, Bhamra, and Schoenheit 2019) are very important components of SSCM, organisations in this study ranked them low on their ranking when considering the environment dimension of TBL. In addition to the need to focus on core competencies, the low ranking given to sustainable purchasing and sustainable distribution may be due to context factors (e.g., country factors) or cost implications.

Finally, for the social dimension, the study also ranked sustainable purchasing and sustainable distribution low. This is a surprising result as, at a nominal level, purchasing and distribution are the two types of activity that require more external engagement with both suppliers, customers and the general public. It is not very clear why these activities were ranked so low for the social dimension, but from the interview findings, the authors would suggest that organisations have decided to focus primarily on certain activities that relate to their competencies and relate these activities, as much as possible, to the TBL. Therefore, while the authors would argue, that sustainable purchasing and sustainable distribution are more strongly able to influence performance of the social dimension, organisations have chosen not to focus on them as much as the other three types of SSCM activity. 


\subsection{Understanding the relative importance Sustainable practices to the TBL}

The findings from the FAHP analysis clearly show that across all the three dimensions of the TBL, sustainable design and sustainable manufacturing are the top two prioritised sustainable practices. Furthermore, the third overall most prioritised sustainable practice is reverse logistics. When combined with the findings from the interviews, the key insights are interesting. They show that manufacturing organisations are clear about their priorities and are fully conversant that their core reason for existence and their core competencies are design and manufacturing. While the need for organisations to focus on their core competencies of design and manufacturing has been discussed in literature (Yang et al. 2017), such focus has not been specifically linked to the lack of willingness to consider certain sustainable supply chain practices as less important to them. The interview findings in this study indicate that such a linkage occurs. In addition to design and manufacturing being core competencies, they also have two other attributes that would boost their high levels of priority. Firstly, they are both 'internal' activities for which the organisations have full or substantial control over. Secondly, the economic benefits from these two activities accrue directly to the organisation. Therefore, bearing in mind the importance earlier ascribed to economic performance, organisations are more likely to prioritise these activities that bring significant economic benefits direct to them.

In contrast, sustainable purchasing and sustainable distribution were ranked lowest across all three TBL dimensions. When compared to the top two sustainable practices as well as the responses from the structured interviews, the reasons for their low ranking become quite clear. The two activities are not core operations of the companies interviewed and while they understand the importance of the activities in achieving their overall sustainability objectives, they have little interest and/or ability in prioritising them. These are activities that are owned and managed by their supply chain partners (suppliers and 3PLs) and key economic benefits will therefore be realised by the supply chain partners, thereby suggesting a disincentive. 
Perhaps, more important and more interesting than the economic disincentive, is the power dynamics of the relationship between the respondents and their supply chain partners. Within the context of supply chain relationships and institutional theory, the interviewed organisations faced significant pressure from their customers to adopt sustainable practices (Seuring, Brix-Asala, and Khalid 2019; Somsuk and Laosirihongthong 2017) and they, in turn, would transfer some of this pressure to their suppliers. However, this study shows that this onward pressure could not always be transmitted for, at least, two reasons. First, many of the suppliers simply do not have the resources to deploy sustainable practices and, secondly, some of their suppliers were recommended by their customers and it is unlikely that the companies would want to place excessive pressure on such suppliers so as not to jeopardize their relationships with customers. This is an important and novel finding. Within the context of supply chain relationships, there has been discussion of organisations having both powerful customers and powerful suppliers (Ghadge et al. 2017; Pressey, Winklhofer, and Tzokas 2009) and finding it difficult to influence either. The power of the customers and suppliers were inherent in their nature and individuality. However, the interview with company $\mathrm{N}$ introduces a new concept of 'power by association'. This study describes this as a state where a company derives its supply chain power, not by its own inherent power or position, but by its association and favour with a more powerful player in the supply chain. In this study, the manifestation is that a particular organisation has limited leverage over most of its suppliers to adopt SSCM practices because the suppliers were not 'chosen' by them but were 'recommended' by their more powerful customers. These power dynamics may impact not just on the ability to coerce sustainability practices but may impact other relationship dynamics such as purchase costs. Nevertheless, rather than adopt a mandating position with such suppliers, the companies have adopted a supportive approach aimed at sharing best practices and encouraging long-term adoption of sustainable practices by their suppliers. 
Reverse logistics practices, overall, was ranked third across the TBL dimensions. When compared to the context of the other practices, this middle ranking seems logical for a number of reasons. First, it is an activity that the organisations have a lot of control over even though it is not their core competence of design and manufacturing. Second, the fact that they will be responsible for driving their reverse logistics operations implies that much of any economic benefits gained will accrue to the company thereby providing and incentive to adopt the practice. Third, legislation is increasingly mandating original equipment manufacturers (OEMs) to set up reverse logistics operation and especially for electronic products which may contain harmful components. Therefore, even if the direct economic benefits of reverse logistics are not as high as those of sustainable design and sustainable manufacturing, there may be a regulatory obligation to set up reverse logistics operations. According to Hsu et al. (2014), regulatory pressure is a key green supply chain driver for broader green supply chain initiatives, including reverse logistics.

\subsection{Theoretical drivers of SSCM practices adoption}

The study findings also provide interesting insights into the relative priority of three different theoretical perspectives in driving the adoption of sustainable practices. With the exception of reverse logistics, the most important driver of the adoption of all the other practices was institutional theory. Therefore, while the interviews identified the importance of customer pressure, government incentive, and direct economic benefits, the most important drivers appear to be the pressure from customers and the effect of government activities/regulation (García-Villarreal, Bhamra, and Schoenheit 2019; Lopes de Sousa Jabbour et al. 2018; Shibin et al. 2017; Tachizawa and Wong 2014; Ansari and Kant 2017; Markley and Davis 2007). However, it is also strongly arguable that complying with customer requirements has a strong economic benefit as it allows the company to maintain or grow its market share. The key drivers suggested above all relate to extrinsic drivers for the adoption of SSCM practices. 
However, extrinsic drivers are not the only relevant factors for implementing SSCM practices. Intrinsic drivers have also been identified as playing an important role in encouraging organisations to adopt SSCM practices. A study by Muller and Kolk (2010) found that management commitment was an important intrinsic factor in encouraging organisations to behave ethically. A more recent study by Morais and Silvestre (2018) linked intrinsically motivated initiatives to supply chain engagement based on structural collaboration. For this study and from a theoretical perspective, intrinsic drivers of SSCM adoption are more likely to be related to RBV - which was the second ranked theoretical driver. In particular, the adoption of sustainable design and sustainable manufacturing practices are underpinned by the intrinsic internal abilities and management motivations of the focal companies. This is an important finding as it provides further support for the earlier suggestion that these practices provide direct economic benefits to the company. Therefore, RBV which comprises competitive advantage (Hong, Zhang, and Ding 2017; Touboulic and Walker 2015; Oliver 1997) was ranked second. The implication, therefore, is a link between intrinsically-motivated RBV and the adoption of practices that provide economic benefits and, therefore, competitive advantage.

In contrast, for sustainable distribution and sustainable purchasing, SNT was ranked higher than RBV. This, again, provides support for the earlier suggestion that these practices are more likely to provide a direct economic benefit to supply chain partners and that encouragement and support provided to supply chain partners are more directed at realising overall sustainability objectives across the supply chain and building good relationships. The implication, therefore, is that SNT is more linked to the extrinsic motivations of developing relationships with supply chain partners.

Finally, for reverse logistics, the most important driver was institution theory and followed by $\mathrm{RBV}$. The implication, therefore, is that although competitive advantage and economic benefits are important drivers of reverse logistics, the pressure from institutional entities such as governments is a very important driver of the adoption of reverse logistics (Esfahbodi, Zhang, and Watson 2016; 
Taticchi et al. 2015) Manufacturers believe that reverse logistics infrastructure is costly compared to the benefits they may accrue (Laosirihongthong, Adebanjo, and Tan 2013).

\section{Conclusion}

This research has contributed to the academic literature and discussion on SSCM by being the first to simultaneously rank TBL dimensions, SSCM practices and theoretical drivers of SSCM implementation. While previous studies have studied these in isolation, there has been no holistic empirical evaluation of the relative importance of these issues. In addition, this study has investigated the complex inter-relationships between the TBL dimensions, SSCM practices and their theoretical drivers. Furthermore, the research has identified an uncommon factor that may affect the power dynamic in SSCM relationships in the form of 'power by association'.

This study reveals that economic performance is perceived as the most important TBL dimension, followed by environment and social dimensions. Nonetheless, there is a slight disagreement between group of academics and industry managers, who perceive environmental dimension is the relatively important one, probably due to their business focus. Among the five sustainable activities within the SCOR dimension, sustainable design is the most important activity affecting TBL goals. This was followed by sustainable manufacturing while sustainable purchasing and sustainable distribution were ranked lowest across all TBL dimensions. Moreover, institutional theory was identified as the most important theory to motivate SSCM adoption followed by RBV and, lastly, SNT.

This study has also identified the concept of 'power by association' whereby the focal company is limited in its ability to influence supplier activities even when such suppliers are nominally less powerful because the supplier has a close relationship with the powerful customer on which the focal company depends. This lack of leverage may distort the willingness and ability of the organisation to actively influence upstream supply chain activities even when they deal with inherently less powerful 
suppliers. A final important finding of this study is that organisations may not be willing to prioritise certain SSCM practices if they do not consider these practices to be central to their core competencies. This may be so even if they understand the benefits of such practices to achieving the TBL.

For the Thai electronic industry, SSCM is adopted based on external driving forces (INS). In addition, resource capability and business competitiveness (RBV) are viewed as the second most important drivers for SSCM implementation. It is interesting to note that supply chain stakeholders and supplier relationships (SNT) are the least important factors pushing Thai electronic companies to adopt SSCM. Regarding SSCM activities, an acceleration of SSCM must be promoted through sustainable design activity as it considers the entire product life cycle from production, usage and disposal. Although, the ultimate achievement of corporate-level sustainability is to balance economic, environment and social aspects, this study indicates that experts in Thai electronic parts/components manufacturing industry still value economic performance as the first priority.

\subsection{Study implications}

This study has implications for government, industry and research. For government, there needs to be a realisation that institutional forces are the most powerful drivers of SSCM adoption. Therefore, in seeking to meet international sustainability commitments, governments must show commitment by enabling policies and regulations that encourage or mandate the adoption of sustainable practices in the supply chain. For industry managers, there needs to be an awareness that different SSCM activities motivate different dimensions of the TBL and if it is not possible to adopt a comprehensive deployment of SSCM activities, they must tailor their resources to those activities that relate to their targets and core competencies. This is because the ability to influence the activities of external stakeholders may be limited. 
For academic research, this study highlights the need to consider multi-theoretical perspectives when dealing with complex and wide-ranging initiatives such as sustainable supply chains. Research must not assume that the theoretical drivers of these initiatives are simplistic in nature.

In conclusion, the study limitations and suggestion for future studies are presented. With respect to limitations, this study was based on findings from one industry sector and so may not reflect other industries with much greater or much less environmental footprints. Future studies may focus on investigating how cultural or country factors relate or influence the deployment of TBL performance measurement. Future studies may also investigate how institutional, RBV and SNT factors affect the likelihood of different types of industries to adopt SSCM.

\section{Acknowledgment}

This research was supported by Thammasat School of Engineering, Thammasat University and Bualuang ASEAN Chair Professorship Scheme. The authors also would like to thank Ms. Metinee Jongpaiboon, research assistant, for conducting data collection and the preliminary analysis.

\section{References}

Accenture. 2017. "UN global compact-accenture strategy CEO study." Accenture Accessed August. https://www.accenture.com/us-en/insight-un-global-compact-ceo-study.

Ageron, Blandine, A. Gunasekaran, and Alain Spalanzani. 2012. "Sustainable supply management: An empirical study." International Journal of Production Economics 140 (1):168-82. doi: http://dx.doi.org/10.1016/j.ijpe.2011.04.007.

Ahi, Payman, and Cory Searcy. 2013. "A comparative literature analysis of definitions for green and sustainable supply chain management." Journal of Cleaner Production 52:329-41. doi: http://dx.doi.org/10.1016/j.jclepro.2013.02.018.

2015. "An analysis of metrics used to measure performance in green and sustainable supply chains." Journal of Cleaner Production 86:360-77. doi: http://dx.doi.org/10.1016/j.jclepro.2014.08.005.

Ansari, Zulfiquar N., and Ravi Kant. 2017. "A state-of-art literature review reflecting 15 years of focus on sustainable supply chain management." Journal of Cleaner Production 142:2524-43. doi: http://dx.doi.org/10.1016/j.jclepro.2016.11.023.

Anvari, Saeedeh, and Metin Turkay. 2017. "The facility location problem from the perspective of triple bottom line accounting of sustainability." International Journal of Production Research? (?):1-22. doi: 10.1080/00207543.2017.1341064.

APICS. 2011. APICS Operations Management Body of Knowledge Framework. 3rd Edition ed. Chicago, IL 60631 USA: APICS Foundation. . 2017. "SCOR Supply Chain Operations Reference Model (Version 12.0)." In. 
Arampantzi, Christina, and Ioannis Minis. 2017. "A new model for designing sustainable supply chain networks and its application to a global manufacturer." Journal of Cleaner Production 156:276-92. doi: https://doi.org/10.1016/j.jclepro.2017.03.164.

Badurdeen, Fazleene, Deepak Lyengar, Thomas J. Goldsby, Haritha Metta, and Sonal Gupta. 2009. "Extending total life-cycle thinking to sustainable supply chain design." International Journal of Product Lifecycle Management 4 (1 to 3):49-67.

Bai, Chunguang, and Joseph Sarkis. 2018. "Honoring complexity in sustainable supply chain research: a rough set theoretic approach (SI:ResMeth)." Production Planning \& Control 29 (16):1367-84. doi: 10.1080/09537287.2018.1535133.

Barney, Jay. 1991. "Firm Resources and Sustained Competitive Advantage." Journal of Management 17 (1):99120. doi: $10.1177 / 014920639101700108$.

Beske, Philip, and Stefan Seuring. 2014. "Putting sustainability into supply chain management." Supply chain management: an international journal 19 (3):322-31. doi: 10.1108/SCM-12-2013-0432.

Bhattacharya, Arijit, Priyabrata Mohapatra, Vikas Kumar, Prasanta Kumar Dey, Malcolm Brady, Manoj Kumar Tiwari, and Sai S. Nudurupati. 2014. "Green supply chain performance measurement using fuzzy ANPbased balanced scorecard: a collaborative decision-making approach." Production Planning \& Control 25 (8):698-714. doi: 10.1080/09537287.2013.798088.

Carter, C. R., and D. S. Rogers. 2008. "A framework of sustainable supply chain management: Moving toward new theory." International Journal of Physical Distribution and Logistics Management 38 (5):360-87.

Chan, Felix T. S., and H. Qi. 2003. "An innovative performance measurement method for supply chain management." Supply Chain Management $8 \quad$ (3):209-23. doi: http://dx.doi.org/10.1108/13598540310484618.

Chang, Da-Yong. 1996. "Applications of the extent analysis method on fuzzy AHP." European Journal of Operational Research 95 (3):649-55. doi: http://dx.doi.org/10.1016/0377-2217(95)00300-2.

Diabat, Ali, Devika Kannan, and K. Mathiyazhagan. 2014. "Analysis of enablers for implementation of sustainable supply chain management - A textile case." Journal of Cleaner Production 83 (Supplement C):391-403. doi: https://doi.org/10.1016/j.jclepro.2014.06.081.

DiMaggio, Paul J., and Walter W. Powell. 1983. "The iron cage revisited: Institutional isomorphism and collective rationality in organizational fields." American Sociological Review 48 (2):147-60.

Esfahbodi, Ali, Yufeng Zhang, and Glyn Watson. 2016. "Sustainable supply chain management in emerging economies: Trade-offs between environmental and cost performance." International Journal of Production Economics 181:350-66. doi: https://doi.org/10.1016/j.ijpe.2016.02.013.

Ganga, Gilberto Miller Devós, and Luiz Cesar Ribeiro Carpinetti. 2011. "A fuzzy logic approach to supply chain performance management." International Journal of Production Economics 134 (1):177-87. doi: http://dx.doi.org/10.1016/j.ijpe.2011.06.011.

García-Villarreal, Enrique, Ran Bhamra, and Martin Schoenheit. 2019. "Critical success factors of medical technology supply chains." Production Planning \& Control DOI: 10.1080/09537287.2019.1572248:120. doi: 10.1080/09537287.2019.1572248.

Geissdoerfer, Martin, Paulo Savaget, Nancy M. P. Bocken, and Erik Jan Hultink. 2017. "The Circular Economy - A new sustainability paradigm?" Journal of Cleaner Production 143:757-68. doi: https://doi.org/10.1016/j.jclepro.2016.12.048.

Geng, Ruoqi, S. Afshin Mansouri, and Emel Aktas. 2017. "The relationship between green supply chain management and performance: A meta-analysis of empirical evidences in Asian emerging economies." International Journal of Production Economics 183:245-58. doi: https://doi.org/10.1016/j.ijpe.2016.10.008.

Ghadge, Abhijeet, Merilena Kaklamanou, Sonal Choudhary, and Michael Bourlakis. 2017. "Implementing environmental practices within the Greek dairy supply chain: Drivers and barriers for SMEs." Industrial Management \& Data Systems 117 (9):1995-2014. doi: 10.1108/IMDS-07-2016-0270.

Glover, J. L., D. Champion, K. J. Daniels, and A. J. D. Dainty. 2014. "An Institutional Theory perspective on sustainable practices across the dairy supply chain." International Journal of Production Economics 152:102-11. doi: https://doi.org/10.1016/j.ijpe.2013.12.027. 
Gold, S., S. Seuring, and P. Beske. 2010. "Sustainable supply chain management and inter-organizational resources: a literature review." Corporate Social Responsibility and Environmental Management 17 (4):230-45. doi: 10.1002/csr.207.

Govindan, Kannan, P. C. Jha, and Kiran Garg. 2016. "Product recovery optimization in closed-loop supply chain to improve sustainability in manufacturing." International Journal of Production Research 54 (5):1463-86. doi: 10.1080/00207543.2015.1083625.

Govindan, Kannan, Roohollah Khodaverdi, and Ahmad Jafarian. 2013. "A fuzzy multi criteria approach for measuring sustainability performance of a supplier based on triple bottom line approach." Journal of Cleaner Production 47:345-54. doi: http://dx.doi.org/10.1016/j.jclepro.2012.04.014.

Grosvold, Johanne, Stefan U. Hoejmose, and Jens K. Roehrich. 2014. "Squaring the circle: Management, measurement and performance of sustainability in supply chains." Supply chain management: an international journal 19 (3):292-305. doi: 10.1108/SCM-12-2013-0440.

Hassini, Elkafi, Chirag Surti, and Cory Searcy. 2012. "A literature review and a case study of sustainable supply chains with a focus on metrics." International Journal of Production Economics 140 (1):69-82. doi: http://dx.doi.org/10.1016/j.ijpe.2012.01.042.

Hollos, Daniel, Constantin Blome, and Kai Foerstl. 2012. "Does sustainable supplier co-operation affect performance? Examining implications for the triple bottom line." International Journal of Production Research 50 (11):2968-86. doi: 10.1080/00207543.2011.582184.

Hong, Jiangtao, Yibin Zhang, and Minqiu Ding. 2017. "Sustainable supply chain management practices, supply chain dynamic capabilities, and enterprise performance." Journal of Cleaner Production. doi: https://doi.org/10.1016/j.jclepro.2017.06.093.

Kuik, Swee Siong, Sev Nagalingam, Premaratne Samaranayake, and Michael William McLean. 2017. "Evaluation of recovery configuration options by product utilisation value." Journal of Manufacturing Technology Management 28 (5):686-710. doi: 10.1108/JMTM-11-2016-0162.

Lai, Kee-hung, and Christina W. Y. Wong. 2012. "Green logistics management and performance: Some empirical evidence from Chinese manufacturing exporters." Omega 40 (3):267-82. doi: http://dx.doi.org/10.1016/j.omega.2011.07.002.

Laosirihongthong, Tritos, Dotun Adebanjo, and Keah Choon Tan. 2013. "Green supply chain management practices and performance." Industrial Management \& Data Systems 113 (8):1088-109. doi: 10.1108/IMDS-04-2013-0164.

Lopes de Sousa Jabbour, Ana Beatriz, Charbel Jose Chiappetta Jabbour, Moacir Godinho Filho, and David Roubaud. 2018. "Industry 4.0 and the circular economy: a proposed research agenda and original roadmap for sustainable operations." Annals of Operations Research 270 (1-2):273-86. doi: https://doi.org/10.1007/s10479-018-2772-8.

Markley, Melissa J., and Lenita Davis. 2007. "Exploring future competitive advantage through sustainable supply chains." International Journal of Physical Distribution \& Logistics Management 37 (9):76374. doi: 10.1108/09600030710840859.

Meixell, Mary J., and Patrice Luoma. 2015. "Stakeholder pressure in sustainable supply chain management: A systematic review." International Journal of Physical Distribution \& Logistics Management 45 (1/2):69-89. doi: 10.1108/IJPDLM-05-2013-0155.

Morais, Dafne O. C., and Bruno S. Silvestre. 2018. "Advancing social sustainability in supply chain management: Lessons from multiple case studies in an emerging economy." Journal of Cleaner Production 199:222-35. doi: https://doi.org/10.1016/j.jclepro.2018.07.097.

Muller, Alan, and Ans Kolk. 2010. "Extrinsic and Intrinsic Drivers of Corporate Social Performance: Evidence from Foreign and Domestic Firms in Mexico." Journal of Management Studies 47 (1):1-26. doi: 10.1111/j.1467-6486.2009.00855.x.

Murphy, Paul Regis, and A. Michael Knemeyer. 2018. Contemporary logistics. Twelfth edition. Global edition. ed. Harlow, United Kingdom

Harlow, England: Pearson.

Nagalingam, Sev V., Swee S. Kuik, and Yousef Amer. 2013. "Performance measurement of product returns with recovery for sustainable manufacturing." Robotics and Computer-Integrated Manufacturing 29 (6):473-83. doi: http://dx.doi.org/10.1016/j.rcim.2013.05.005. 
Oliver, Christine. 1997. "Sustainable Competitive Advantage: Combining Institutional and Resource-Based Views." Strategic Management Journal 18 (9):697-713.

Prasad, Dayal S., Rudra P. Pradhan, Kunal Gaurav, Partha P. Chatterjee, Inderpal Kaur, Saurav Dash, and Sagar Nayak. 2018. "Analysing the critical success factors for implementation of sustainable supply chain management: an Indian case study." Decision. 45 (1):3-25. doi: 10.1007/s40622-017-0171-7.

Pressey, Andrew D., Heidi M. Winklhofer, and Nikolaos X. Tzokas. 2009. "Purchasing practices in small- to medium-sized enterprises: An examination of strategic purchasing adoption, supplier evaluation and supplier capabilities." Journal of Purchasing and Supply Management 15 (4):214-26. doi: https://doi.org/10.1016/j.pursup.2009.03.006.

Rajeev, A., Rupesh K. Pati, Sidhartha S. Padhi, and Kannan Govindan. 2017. "Evolution of sustainability in supply chain management: A literature review." Journal of Cleaner Production 162 (Supplement C):299-314. doi: https://doi.org/10.1016/j.jclepro.2017.05.026.

Reefke, Hendrik, and David Sundaram. 2017. "Key themes and research opportunities in sustainable supply chain management - identification and evaluation." Omega 66:195-211. doi: https://doi.org/10.1016/j.omega.2016.02.003.

Saaty, Thomas L. 1994. "How to make a decision: The analytic hierarchy process." Interfaces 24 (6):19-43.

Salari, Meysam, and Nadia Bhuiyan. 2016. "A proposed approach to improve current sustainable product development." Journal of Industrial and Production Engineering 33 (5):297-307. doi: 10.1080/21681015.2016.1172122.

Schaltegger, S., and R. Burritt. 2014. "Measuring and managing sustainability performance of supply chains: review and sustainability supply chain management framework." Supply Chain Management 19 (3):232-41. doi: 10.1108/SCM-02-2014-0061.

Sen, Subir. 2009. "Linking Green Supply Chain Management and Shareholder Value Creation." IUP Journal of Supply Chain Management 6 (3/4):95-109.

Seuring, Stefan, Carolin Brix-Asala, and Raja Usman Khalid. 2019. "Analyzing base-of-the-pyramid projects through sustainable supply chain management." Journal of Cleaner Production 212:1086-97. doi: https://doi.org/10.1016/j.jclepro.2018.12.102.

Shepherd, Craig, and Hannes Günter. 2011. "Measuring Supply Chain Performance: Current Research and Future Directions." In Behavioral Operations in Planning and Scheduling, edited by Jan C. Fransoo, Toni Waefler and John R. Wilson, 105-21. Berlin, Heidelberg: Springer Berlin Heidelberg.

Shibin, K. T., Rameshwar Dubey, Angappa Gunasekaran, Benjamin Hazen, David Roubaud, Shivam Gupta, and Cyril Foropon. 2017. "Examining sustainable supply chain management of SMEs using resource based view and institutional theory." Annals of Operations Research https://doi.org/10.1007/s10479017-2706-x. doi: 10.1007/s10479-017-2706-x.

Somsuk, Nisakorn, and Tritos Laosirihongthong. 2017. "Prioritization of applicable drivers for green supply chain management implementation toward sustainability in Thailand." International Journal of Sustainable Development \& World Ecology 24 (2):175-91. doi: 10.1080/13504509.2016.1187210.

Tachizawa, Elcio M., and Chee Yew Wong. 2014. "Towards a theory of multi-tier sustainable supply chains: a systematic literature review." Supply chain management: an international journal 19 (5/6):643-63. doi: 10.1108/SCM-02-2014-0070.

Taticchi, Paolo, Patrizia Garengo, Sai S. Nudurupati, Flavio Tonelli, and Roberto Pasqualino. 2015. "A review of decision-support tools and performance measurement and sustainable supply chain management." International Journal of Production Research 53 (21):6473-94. doi: 10.1080/00207543.2014.939239.

Thamsatitdej, P., S. Boon-itt, P. Samaranayake, M. Wannakarn, and T. Laosirihongthong. 2017. "Eco-design practices towards sustainable supply chain management: interpretive structural modelling (ISM) approach." International Journal of Sustainable Engineering 10 (6):326-37. doi: 10.1080/19397038.2017.1379571.

Touboulic, Anne, and Helen Walker. 2015. "Theories in sustainable supply chain management: a structured literature review." International Journal of Physical Distribution \& Logistics Management 45 (1/2):1642. doi: 10.1108/IJPDLM-05-2013-0106.

Tseng, Ming-Lang, Ming K. Lim, Wai-Peng Wong, Yi-Chun Chen, and Yuanzhu Zhan. 2016. "A framework for evaluating the performance of sustainable service supply chain management under uncertainty." International Journal of Production Economics. doi: https://doi.org/10.1016/j.ijpe.2016.09.002. 
Turrisi, Mario, Bruccoleri Manfredi, and Salvatore Cannella. 2013. "Impact of reverse logistics on supply chain performance." International Journal of Physical Distribution \& Logistics Management 43 (7):564-85.

Wang, Zhihong, and Joseph Sarkis. 2013. "Investigating the relationship of sustainable supply chain management with corporate financial performance." International Journal of Productivity and Performance Management 62 (8):871-88. doi: 10.1108/IJPPM-03-2013-0033.

Winter, Marc, and A. Michael Knemeyer. 2013. "Exploring the integration of sustainability and supply chain management: Current state and opportunities for future inquiry." International Journal of Physical Distribution \& Logistics Management 43 (1):18-38. doi: 10.1108/09600031311293237.

Yang, Ying, Biao Yang, Paul Humphreys, Ronan McIvor, and Trevor Cadden. 2017. "An investigation into Ebusiness service in the UK telecommunication manufacturing industry." Production Planning \& Control 28 (3):256-66. doi: 10.1080/09537287.2017.1280622. 